$\begin{array}{ll}\text { Received } & 08.06 .2018 \\ \text { Reviewed } & 11.07 .2018\end{array}$

Accepted 13.07.2018

A - study design

B - data collection

C - statistical analysis

D - data interpretation

E - manuscript preparation

$\mathbf{F}$ - literature search

\section{Assessment of the CROPWAT 8.0 software reliability for evapotranspiration and crop water requirements calculations}

\author{
Raisa A. VOZHEHOVA ${ }^{\text {1) ABCDEF }}$, Yurii O. LAVRYNENKO ${ }^{2)}$ ABCDEF, \\ Serhii V. KOKOVIKHIN ${ }^{3)}$ ABCDEF, Pavlo V. LYKHOVYD ABCDEF $ه$, \\ Iryna M. BILIAIEVA ${ }^{\text {5) DEF }}$, Antonina V. DROBITKO ${ }^{6)}$ ABCDEF, \\ Vasyl V. NESTERCHUK ${ }^{7) ~ D E F}$
}

\footnotetext{
1) orcid.org/0000-0002-3895-5633; Institute of Irrigated Agriculture, Naddniprianske, Ukraine

2) orcid.org/0000-0001-9442-8793; Institute of Irrigated Agriculture, Naddniprianske, Ukraine

3) orcid.org/0000-0002-1687-6889; Institute of Irrigated Agriculture, Naddniprianske, Ukraine

4) orcid.org/0000-0002-0314-7644; Institute of Irrigated Agriculture, Naddniprianske, 73483 Kherson, Ukraine; e-mail: pavel.likhovid@gmail.com

5) orcid.org/0000-0003-0688-4209; Institute of Irrigated Agriculture, Naddniprianske, Ukraine

6) orcid.org/0000-0002-6492-4558; Institute of Irrigated Agriculture, Naddniprianske, Ukraine

7) orcid.org/0000-0003-4809-1442; Institute of Irrigated Agriculture, Naddniprianske, Ukraine
}

For citation: Vozhehova R. A., Lavrynenko Y. O., Kokovikhin S. V., Lykhovyd P. V., Biliaieva I. M., Drobitko A. V., Nesterchuk V. V. 2018. Assessment of the CROPWAT 8.0 software reliability for evapotranspiration and crop water requirements calculations. Journal of Water and Land Development. No. 39 p. 147-152. DOI: 10.2478/jwld-2018-0070.

\begin{abstract}
The results of the study devoted to assessment of accuracy and reliability of the CROPWAT 8.0 software application calculations of the evapotranspiration and crop water requirements are represented in the article.

The study was based on the results of the perennial field experiments, conducted during the period from 2012 to 2017 at the irrigated lands of the South of Ukraine with different crops, namely: sweet corn, grain corn, soybean, sorghum. We assessed accuracy of the CROPWAT 8.0 software application by the comparison of the calculated values with the real ones. We determined considerable differences between the calculated crops evapotranspiration values and crops irrigation requirements and the real ones obtained in the field experiments. The difference was the most essential in case of the dripirrigated sweet corn crop and averaged to $46.05 \%$ for evapotranspiration and $89.20 \%$ for irrigation water requirements, correspondingly. Overhead sprinkler irrigated crops are likely to be more suitable for accurate evapotranspiration prediction by using the CROPWAT 8.0. The slightest discrepancy between the calculated and actual values of the studied parameters were determined on the overhead sprinkler irrigated grain corn crops, where the differences averaged just to $15.86 \%$ for evapotranspiration and $41.63 \%$ for irrigation norm. The results of the study gave us an opportunity to conclude that CROPWAT 8.0 software application should not be used without previous calibration and adjustment of the crop coefficients for the concrete agricultural production conditions.
\end{abstract}

Key words: CROPWAT, evapotranspiration, grain corn, irrigation, sweet corn, soybean, sorghum, water requirements

\section{INTRODUCTION}

Water is usually considered to be a renewable natural resource. But its improper distribution among the world and increasing demands can make a drastic effect on its availability and lead to significant freshwater scarcity in the nearest future [TARJUELO et al. 2010]. Recently conducted scientific studies have predicted increase in freshwater demands up to $80 \%$ by 2050 [FLÖRKE et al. 2018]. 
Agriculture is the main and biggest consumer of freshwater. About $70-80 \%$ (and in the arid zones up to $90 \%$ ) of freshwater is used for agricultural purposes, particularly, for crop production at the irrigated lands [MOLDEN 2007]. Increasing demands for freshwater are highly likely to impact agricultural water supply. Proper agricultural water management is one of the most important issues that are on the table nowadays. Scientifically based and sensible water management is but the only way to provide crop production sustainability in the arid regions, which are very water-dependent ones. Rationale irrigation water use can significantly improve natural water resources use through preventing its pollution and improper application.

Precise evapotranspiration calculation is necessary for scientifically based irrigation water management. There are different methods for evapotranspiration calculation: masstransfer based methods, radiation based methods and temperature-based methods [PENMAN 1956; USHKARENKO 1994; Xu, SINGH 2002]. The Penman-Monteith method is considered to be one of the most reliable and comprehensive methods for estimation of evapotranspiration and crop water requirements, and it is actively used worldwide [ABEDINPOUR 2017; NORELDIN et al. 2016]. The CROPWAT 8.0 software application created by FAO specialists provides an opportunity of automation of all the necessary calculations for evapotranspiration determination. The application uses Penman-Monteith method as a base for further calculations, namely: evapotranspiration, irrigation water requirements for separate crops and crop-rotations, building of the irrigation schedules, etc. It is widely used for defining crops water requirements all over the world [FENG et al. 2007; STANCALIE et al. 2010; SURENDRAN et al. 2015]. It is likely to be one of the most popular tools for designing the irrigation schedule of crops [GEORGE et al. 2000]. At the same time recent studies established that there are better than Penman-Monteith models for evapotranspiration assessment now. For example, the BlaneyCriddle and Abtew models are the best ones for estimating the evapotranspiration $\left(E T_{o}\right)$ in the arid and semiarid regions, respectively, and the modified Hargreaves-Samani 2 model represented the best performance in the Mediterranean and very humid regions [VALIPOUR et al. 2017]. Also, scientists mentioned that it is unlikely that the method of Penman-Monteith should be used in the world practice, because it has a number of potential restrictions and does not take into account some crucial points [CHEREMISINOV, CHEREMISINOV 2016]. The main goal of our study was to assess real accuracy and reliability of the CROPWAT 8.0 calculations both for sprinkler overhead and drip irrigated crops grown in different conditions of the South of Ukraine, so as to give substantiated recommendations for scientists and farmers on use of the application for practical purposes and to establish whether it is suitable for water management improvement in irrigated agriculture.

\section{MATERIALS AND METHODS}

All the field experiments were conducted in four replications by using the split plot design method at the irrigated lands of agricultural farms and research institutions.
1. Field experiments with sweet corn were conducted at the irrigated lands of the Agricultural Cooperative Farm "Radianska Zemlia" (Bilozerskiy district of Kherson region, Ukraine; coordinates of the experimental field: latitude $46^{\circ} 43$ ' $42^{\prime \prime} \mathrm{N}$, longitude $32^{\circ} 17^{\prime} 38^{\prime}$ ' E, altitude $42 \mathrm{~m}$ ). Size of the experimental plot was $30 \mathrm{~m}^{2}$. The soil was represented by the dark-chestnut solonets soil with humus content in the $0-50 \mathrm{~cm}$ soil layer of $2.5 \%$, lightlyhydrolized nitrogen content (determined by the Kornfield method) of $35 \mathrm{mg} \cdot \mathrm{kg}^{-1}$ [SHKONDE 1971], mobile phosphorus content (determined by the methodology of Machygin) of $32 \mathrm{mg} \cdot \mathrm{kg}^{-1}$, exchangeable potassium content (determined by the methodology of Machygin) of $430 \mathrm{mg} \cdot \mathrm{kg}^{-1}$ [ARINUSHKINA 1970]. The water-holding capacity of the soil in the $0-100 \mathrm{~cm}$ layer is $19.9 \%$. The wilting point is $7.2 \%$ correspondingly. We used Brusnytsia (standard sweet su cultivar, originated at the Skvyrska research station of the Institute of Agroecology and Use of Environment - Ukr. Skvyrska doslidna stantsiia Instytutu Agroekologii ta Pryrodokorystuvanniia) crop cultivar in the field experiments. Sweet corn cultivation technology in the field experiments was common for growing under the irrigated conditions in the South of Ukraine. Soil moisture during the sweet corn vegetation was kept up at $80 \%$ of the field water-holding capacity by the means of drip irrigation. We placed drip tape in every row of sweet corn crops. We used Eurodrip 5 mil tape with spacing of drippers of 20 $\mathrm{cm}$ and discharge rate of $1.2 \mathrm{dm}^{3} \cdot \mathrm{h}^{-1}$. Water application doses were: in $2014-10$ times at the rate of $5 \mathrm{~mm}$ until the stage of 7-8 leaves of crop and 12 times at the rate of 10 $\mathrm{mm}$ in the rest of the period; in $2015-6$ times at the rate of $5 \mathrm{~mm}$ until the stage of 7-8 leaves of crop and 9 times at the rate of $10 \mathrm{~mm}$ in the rest of the period; in $2016-8$ times at the rate of $5 \mathrm{~mm}$ until the stage of 7-8 leaves of crop and 12 times at the rate of $10 \mathrm{~mm}$ in the rest of the period.

2. Field experiments with grain corn, soybean and sorghum were conducted at the irrigated lands of the Institute of Irrigated Agriculture of the National Academy of Agrarian Sciences of Ukraine (coordinates of the experimental field: latitude $46^{\circ} 44^{\prime} 33^{\prime \prime} \mathrm{N}$, longitude $32^{\circ} 42^{\prime} 28^{\prime \prime} \mathrm{E}$, altitude $42 \mathrm{~m}$ ). Size of the experimental plot was $300 \mathrm{~m}^{2}$. The soil was represented by the dark-chestnut solonets middleloamy soil with humus content in the $0-50 \mathrm{~cm}$ soil layer of $2.15 \%$. The total nitrogen content (determined by the colorimeter method) averaged to $0.17 \%$, mobile phosphorus content (determined by the methodology of Machygin) averaged to $30-40 \mathrm{mg} \cdot \mathrm{kg}^{-1}$, exchangeable potassium content (determined by the methodology of Machygin) averaged to $350-450 \mathrm{mg} \cdot \mathrm{kg}^{-1}$ [ARINUSHKINA 1970]. The water-holding capacity of the soil in the $0-100 \mathrm{~cm}$ layer is $21.3 \%$. The wilting point is $9.5 \%$ correspondingly. We used Kahovskii grain corn hybrid (FAO 380, originated at the Institute of Irrigated Agriculture - Ukr. Instytut zroshuvanoho zemlerobstva), Apollon soybean cultivar (originated at the Institute of Irrigated Agriculture) and Sontsedar sorghum hybrid (originated by the Nuseed company - Australia) in the field experiments. Cultivation technologies of all the studied crops in the field experiments were common for growing under the irrigated condi- 
tions in the South of Ukraine. Soil moisture during the grain corn, soybean and sorghum crops vegetation was kept up at $70 \%$ of the field water-holding capacity. The irrigation was conducted by the means of overhead sprinkler irrigation machine DDA-100MA. Intensity of sprinkling of the irrigation machine was $2.5 \mathrm{~mm} \cdot \mathrm{min}^{-1}$. Water application doses at the grain corn crops were: in 2012, $2014,2015-7$ times at the rate of $50 \mathrm{~mm}$; in 2013 - once at the rate of $35 \mathrm{~mm}$ at the early stage and 5 times at the rate of $50 \mathrm{~mm}$ in the rest of the period; in 2017 - once at the rate of $30 \mathrm{~mm}$ at the early stage and 7 times at the rate of $50 \mathrm{~mm}$ in the rest of the period. Water application doses at the soybean crops were: in 2014 - 10 times at the rate of $40 \mathrm{~mm}$; in 2017 - once at the rate of $30 \mathrm{~mm}$ at the early stage and 5 times at the rate of $50 \mathrm{~mm}$ in the rest of the period. Water application doses at the sorghum crops were 10 times at the rate of $40 \mathrm{~mm}$.

The trials were carried out during the period from 2012 to 2017. Terms of sowing and harvesting of each crop are given in the Table 1 .

Table 1. Terms of sowing and harvesting of the studied crops in the field experiments

\begin{tabular}{|c|c|c|}
\hline \multirow{2}{*}{ Crops } & \multicolumn{2}{|c|}{ Terms } \\
\cline { 2 - 3 } & of sowing & of harvesting \\
\hline \multirow{3}{*}{ Sweet corn } & 1.05 .2014 & 23.07 .2014 \\
\cline { 2 - 3 } & 22.05 .2015 & 8.08 .2015 \\
\cline { 2 - 3 } & 21.05 .2016 & 7.08 .2016 \\
\hline \multirow{4}{*}{ Grain corn } & 30.04 .2012 & 29.08 .2012 \\
\cline { 2 - 3 } & 3.05 .2013 & 10.09 .2013 \\
\cline { 2 - 3 } & 5.05 .2014 & 16.09 .2014 \\
\cline { 2 - 3 } & 7.05 .2015 & 23.09 .2015 \\
\cline { 2 - 3 } & 10.05 .2017 & 5.09 .2017 \\
\hline \multirow{4}{*}{ Soybean } & 12.05 .2014 & 25.09 .2014 \\
\cline { 2 - 3 } & 11.05 .2017 & 12.09 .2017 \\
\hline Sorghum & 21.04 .2017 & 16.09 .2017 \\
\hline
\end{tabular}

Source: own elaboration.

The meteorological data was provided by the Kherson Hydro-Meteorological Center network stations which are situated close to the experimental fields. We used the monthly meteorological data for calculations. The Penman-Monteith method was used for calculation of the total evapotranspiration within the CROPWAT 8.0 software application [ALLEN et al. 1998; SMITH 1992]. We used key model parameters such as crops coefficients and climatic data assessment method recommended by FAO. All the mathematical calculations were conducted within CROPWAT 8.0 software application and no other calculation methodologies were used. The options used in CROPWAT 8.0 are represented in the Table 2 .

Sweet corn root depth used in calculations was $30 \mathrm{~cm}$ at the initial stage and $50 \mathrm{~cm}$ in the rest of the growth period. Other crops' root depths used in calculations were $30 \mathrm{~cm}$ at the initial stage and $70 \mathrm{~cm}$ in the rest of the growth period.

Crop coefficients used in the trials are given in the Table 3 .

Average duration of the main crop development periods used in calculations is given in the Table 4 .
Table 2. CROPWAT 8.0 options used for determination of the evapotranspiration and crop water requirements calculations

\begin{tabular}{|l|l|}
\hline \multicolumn{1}{|c|}{ Index or parameter } & \multicolumn{1}{c|}{ Option for calculations } \\
\hline$E T_{\mathrm{o}}$ Penman-Monteith & $\begin{array}{l}E T_{\mathrm{o}} \text { Penman calculated from temperature data } \\
\text { (other data estimated) }\end{array}$ \\
\hline Rainfall & dependable rain (FAO/AGLW formula) \\
\hline Irrigation timing & irrigate at critical depletion \\
\hline Irrigation application & refill soil to field capacity \\
\hline Irrigation efficiency & $70 \%$ \\
\hline
\end{tabular}

Source: own elaboration.

Table 3. Crop coefficients used in the calculations within CROPWAT 8.0

\begin{tabular}{|c|c|c|}
\hline Crop & Stage of development & Crop coefficient \\
\hline \multirow{3}{*}{ Sweet corn } & initial & 0.30 \\
\cline { 2 - 3 } & mid-season & 1.00 \\
\cline { 2 - 3 } & late season & 0.20 \\
\hline \multirow{3}{*}{ Grain corn } & initial & 0.30 \\
\cline { 2 - 3 } & mid-season & 1.00 \\
\cline { 2 - 3 } & late season & 0.20 \\
\hline \multirow{3}{*}{ Soybean } & initial & 0.30 \\
\cline { 2 - 3 } & mid-season & 1.00 \\
\cline { 2 - 3 } & late season & 0.40 \\
\hline \multirow{3}{*}{ Sorghum } & initial & 0.40 \\
\cline { 2 - 3 } & mid-season & 1.00 \\
\cline { 2 - 3 } & late season & 0.50 \\
\hline
\end{tabular}

Source: own study.

Table 4. Duration of the main crop development periods used in calculations within CROPWAT 8.0

\begin{tabular}{|c|c|c|}
\hline Crop & Period & Duration (days) \\
\hline \multirow{4}{*}{ Sorghum } & initial & 20 \\
\cline { 2 - 3 } & development & 35 \\
\cline { 2 - 3 } & mid-season & 50 \\
\cline { 2 - 3 } & late season & 30 \\
\hline \multirow{4}{*}{ Soybean } & initial & 20 \\
\cline { 2 - 3 } & development & 30 \\
\cline { 2 - 3 } & mid-season & 50 \\
\hline \multirow{5}{*}{ Grain corn } & late season & 20 \\
\cline { 2 - 3 } & initial & 25 \\
\cline { 2 - 3 } & development & 35 \\
\cline { 2 - 3 } & mid-season & 30 \\
\hline \multirow{5}{*}{ Sweet corn } & late season & 30 \\
\cline { 2 - 3 } & initial & 20 \\
\cline { 2 - 3 } & development & 20 \\
\cline { 2 - 3 } & mid-season & 25 \\
\hline \multirow{5}{*}{} & late season & 15 \\
\hline
\end{tabular}

Source: own elaboration.

The real values of the above-mentioned indices were established by using the method of the field water balance as the sum of effective precipitation, available to plants soil moisture and applied irrigation water amounts. Precipitation amounts were established by using the pluviometers. Soil moisture was determined by the balance-drier method. The soil samples were collected from every $10 \mathrm{~cm}$ layer down to the depth of $100 \mathrm{~cm}$ at the sprouting stage and in the pre-harvesting period. The amounts of applied irrigation water were accounted by using the special watercounters [USHKARENKO et al. 2014]. 
Table 5. Total water consumption values for the studied crops (real and predicted by the CROPWAT $8.0-\mathrm{CW} 8.0$ )

\begin{tabular}{|c|c|c|c|c|c|c|c|c|c|}
\hline \multirow{2}{*}{ Year } & \multicolumn{3}{|c|}{$E T_{o}(\mathrm{~mm})$} & \multicolumn{3}{|c|}{$I W A(\mathrm{~mm})$} & \multicolumn{3}{|c|}{$S M$ plus $E R(\mathrm{~mm})$} \\
\hline & CW 8.0 & real & CW 8.0 to real (\%) & CW 8.0 & real & $\mathrm{CW} 8.0$ to real $(\%)$ & CW 8.0 & real & CW 8.0 to real (\%) \\
\hline \multicolumn{10}{|c|}{ Sweet corn } \\
\hline 2014 & 427.7 & 287.2 & 148.92 & 317.8 & 170.0 & 186.94 & 109.9 & 117.2 & 93.77 \\
\hline 2015 & 387.4 & 275.1 & 140.82 & 235.3 & 120.0 & 196.08 & 152.1 & 155.1 & 98.07 \\
\hline 2016 & 398.9 & 269.1 & 148.23 & 298.4 & 160.0 & 186.50 & 100.5 & 109.1 & 92.12 \\
\hline Mean & 404.7 & 277.1 & 146.05 & 283.8 & 150.0 & 189.20 & 120.8 & 127.1 & 95.04 \\
\hline \multicolumn{10}{|c|}{ Grain corn } \\
\hline 2012 & 623.3 & 545.1 & 114.35 & 462.7 & 350.0 & 132.20 & 160.6 & 195.1 & 82.32 \\
\hline 2013 & 602.5 & 464.0 & 129.85 & 468.5 & 285.0 & 164.39 & 134.0 & 179.0 & 74.86 \\
\hline 2014 & 652.5 & 557.4 & 117.06 & 505.9 & 350.0 & 144.54 & 146.6 & 207.4 & 70.68 \\
\hline 2015 & 668.8 & 555.6 & 120.37 & 485.0 & 350.0 & 138.57 & 183.8 & 205.6 & 89.40 \\
\hline 2017 & 572.6 & 570.2 & 100.10 & 506.8 & 380.0 & 144.80 & 67.0 & 190.2 & 35.23 \\
\hline Mean & 623.9 & 538.5 & 115.86 & 485.8 & 343.0 & 141.63 & 138.4 & 195.5 & 70.79 \\
\hline \multicolumn{10}{|c|}{ Soybean } \\
\hline 2014 & 685.6 & 546.5 & 125.45 & 531.3 & 400.0 & 132.83 & 155.2 & 146.5 & 105.94 \\
\hline 2017 & 611.5 & 464.6 & 131.62 & 545.7 & 280.0 & 194.89 & 65.8 & 184.6 & 35.64 \\
\hline Mean & 648.6 & 505.6 & 128.28 & 538.5 & 340.0 & 158.38 & 110.5 & 165.6 & 66.73 \\
\hline \multicolumn{10}{|c|}{ Sorghum } \\
\hline 2017 & 736.0 & 570.5 & 129.00 & 638.2 & 400.0 & 159.55 & 97.8 & 170.5 & 57.36 \\
\hline
\end{tabular}

Source: own study.

\section{RESULTS AND DISCUSSION}

Results of the study showed significant discrepancy between the calculated by the CROPWAT 8.0 software application and real evapotranspiration and irrigation water requirements of the drip and overhead sprinkler irrigated crops (Tab. 5).

In case of the drip irrigated sweet corn the difference averaged to the values of 112.3-140.5 mm for evapotranspiration and to $115.3-147.8 \mathrm{~mm}$ for the irrigation water amounts. The CROPWAT 8.0 model of the crop water requirements and use provided up to $140.82-148.92 \%$ higher values of evapotranspiration and up to 186.50 $196.08 \%$ higher values of the required irrigation water amounts. It is obvious, that the main reason of the higher evapotranspiration values provided by the CROPWAT 8.0 is overestimation of the irrigation water requirements, while the values of the soil moisture and effective rainfall amounts were estimated by the software application with fairly high accuracy of 92.12-98.07\%.

The evapotranspiration of the overhead sprinkler irrigated grain corn calculated by the means of the CROPWAT 8.0 software application was also considerably higher than the actual one. The difference averaged to 2.4$138.5 \mathrm{~mm}$, greatly fluctuating in dependence on the climatic conditions of the year of study. The higher evapotranspiration rates were provided by the software application due to the overestimation of the irrigation water requirements (up to $32.20-64.39 \%$ overestimation rate) and underestimation of the available natural moisture (down to 10.60$64.77 \%$ underestimation rate). The same picture is observed on the other studied crops, viz., soybean and sorghum. Overestimation of the above-mentioned crops evapotranspiration was also connected with inaccuracy in the irrigation water requirements and natural moisture conditions assessment. The most crucial over-watering was suggested by the software in soybean crops in 2017, when predicted by the CROPWAT 8.0 irrigation water requirements were estimated as $194.89 \%$ to the real ones. The most inaccurate soil moisture and effective rainfall amounts calculation was provided by the CROPWAT 8.0 in 2017, when natural moisture conditions were underestimated to $64.36 \%$ on soybean crops and $42.64 \%$ on sorghum crops, comparatively to the actually fixed field values. The discrepancy in the evapotranspiration on soybean crops averaged to $139.1-146.9 \mathrm{~mm}$, and to $165.5 \mathrm{~mm}$ on sorghum crops, respectively.

We consider several reasons of such a discrepancy in the evapotranspiration and irrigation water requirements estimation. We cannot put the obtained in our study differences down to imperfection of the CROPWAT 8.0 calculation algorithms. The fact that the differences depended on the climatic conditions of each year and crop biological features (the highest discrepancy was stated in dry years on the late-ripening sorghum and soybean crops) we suggest that the main problem lays in the crop coefficients, which are not actually adjusted for the certain climatic conditions. We conjecture that the crops coefficients by the stages of their development, which were provided by FAO and used in the CROPWAT 8.0 calculations, are not suitable for every agricultural production conditions and must be corrected with taking into account a number of specific parameters, for example, such as irrigation method used (drip irrigation, subsoil irrigation, furrow or overhead sprinkler irrigation, etc.), cultivation technology peculiarities, hybrid or variety morphological and biological features, climatic conditions of the zone, etc. Our conclusions are concordant with the results of some other scientific researches, reporting about the necessity of thorough adjustment of the crop coefficients for the drip-irrigated conditions of the concrete climatic zone for getting accurate crop water use predictions by the Penman-Monteith calculations within CROPWAT 8.0 software application [ROMASHCHENKO et al. 2016; ZHURAVLEV 2016]. That is why a number of studies, conducted in the non-typical agricultural conditions, a reports about evident inaccuracy (averaged to 8.3$13.5 \%$ depending on the irrigation method used) of the Penman-Monteith calculations in estimating evapotranspi- 
ration and irrigation water requirements for different crops [KHAMRAEV et al. 2016]. The results of scientific researches led to conclusion, that biological crop coefficient proposed by FAO for the calculations within the CROPWAT 8.0 software application are not suitable for every agricultural zone, and should be corrected due to the real crop requirements in certain soil and climatic conditions. Besides, natural humidification conditions also might be estimated by the software inaccurately, especially, when calculations are carried out for unusual, non-typical weather conditions [STULINA 2010]. Therefore we concluded that CROPWAT 8.0 software complex cannot be used "as it is" for precise irrigation scheduling as it has been earlier reported in some works [VOZHEHOV et al. 2016]. As a result, we recommend to use the CROPWAT 8.0 software application for the evapotranspiration and crops irrigation water requirements calculations only after previously conducted thorough adjustment of the crop coefficients.

\section{CONCLUSIONS}

The CROPWAT 8.0 software application is an interesting and modern tool for agricultural water management. It is easy in use, but it is not accurate enough and needs previous adjustments and thorough calibration of the crop coefficients for getting adequate predictions of the crop water requirements under the concrete conditions of agricultural production. We strongly recommend the CROPWAT 8.0 software application to be used in agricultural science and practice carefully and only after adjustment and carrying out field testing to guarantee efficient and rational agricultural water management.

\section{REFERENCES}

ABEDINPOUR M. 2017. Wheat water use and yield under different salinity of irrigation water. Journal of Water and Land Development. No. 33 p. 3-9. DOI 10.1515/jwld-2017-0013.

Allen R.G., Pereira L.S., RAES D., Smith M. 1998. Crop evapotranspiration - Guidelines for computing crop water requirements. FAO Irrigation and Drainage Paper. No. 56. Rome. FAO. ISBN 92-5-104219-5 pp. 300.

ARINUSHKINA E. V. 1970. Rukovodstvo po khimicheskomu analizu pochv [Guide on a chemical analysis of soils]. Moscow. Moscow State University pp. 487.

Cavero J., Farre I., Debaeke P., FACI J.M. 2000. Simulation of maize yield under water stress with the EPICphase and CROPWAT models. Agronomy Journal. No. 92 p. 679-690. DOI 10.2134/agronj2000.924679x.

Cheremisinov A.A., CHEREMisinOv A.Yu. 2016. Obzor raschetnykh metodov opredeleniya summarnogo ispareniya oroshaemykh sel'skokhozyaystvennykh poley [Review of calculating methods for evapotranspiration of irrigated fields]. Nauchnyi Zhurnal Rossiiskogo Nauchno-issledovatelskogo Instituta Problem Melioratsyi. No. 1(21) p. 113-133.

FenG Z., LiU D., ZHANG Y. 2007. Water requirements and irrigation scheduling of spring maize using GIS and CropWat model in Beijing-Tianjin-Hebei region. Chinese Geographical Science. No. 17(1) p. 56-63. DOI 10.1007/s11769-007-0056-3.

FLÖRKE M., SCHNEIDER C., MCDONALD R.I. 2018. Water competition between cities and agriculture driven by climate change and urban growth. Nature Sustainability. No 1(1) p. 51-58.
George B.A., Shende S.A., Raghuwanshi N.S. 2000. Development and testing of an irrigation scheduling model. Agricultural water management. No. 46(2) p. 121-136.

Khamraev S.R., BeZborodov Yu.G., SHAMSIEV A.S. 2016. Fakticheske i raschetnye pokazateli vodopotrebleniya khlopchatnika $\mathrm{v}$ usloviyakh deficita orositelnoy vody [Actual and calculated indexes of cotton-plants water use in conditions of irrigation water deficit]. Irrigatsiya va melioratsiya. No. 1(3) p. 5-7.

MoLDEN D. 2007. Water for food. Water for life: A comprehensive assessment of water management in agriculture. Routledge. International Water Management Institute (IWMI) and FAO. ISBN 978-184-4073-96-2 pp. 664.

Noreldin T., OUdA S., AMER A. 2016. Agro-climatic zoning in Egypt to improve irrigation water management. Journal of Water and Land Development. No. 31 p. 113-117. DOI 10.1515/jwld-2016-0041.

PenMAN H.L. 1956. Evaporation. An introductory survey. Netherlands Journal of Agricultural Science. Vol. 4 p. 9-29.

RomashchenKo M., ShatKowski A., ZhURAVleV O. 2016. Features of application of the Penman-Monteith method for conditions of a drip irrigation of the steppe of Ukraine (on example of grain corn). Journal of Water and Land Development. No. 31 p. 123-127. DOI 10.1515/jwld-2016-0043.

SHKONDE E.I. 1971. O primenimosti metoda Kornfielda dlya opredeleniya potrebnosti pochv $\mathrm{v}$ azotnykh udobreniyakh [About using the methodology of Kornfield for estimation of needs of soils in nitrogen fertilizers]. Chemistry in Agriculture. No. 12 p. $50-60$

SMITH M. 1992. CROPWAT: A computer program for irrigation planning and management. FAO Irrigation and Drainage Paper. No. 46. Rome. FAO. ISBN 978-925-1031-06-3 pp. 133.

Stancalie G., Marica A., Toulios L. 2010. Using earth observation data and CROPWAT model to estimate the actual crop evapotranspiration. Physics and Chemistry of the Earth, Parts A/B/C. No. 35(1-) p. 25-30. DOI 10.1016/j.pce.2010.03.013.

StUlinA G.V. 2010. Rekomendatsii po gidromodul'nomu rayonirovaniyu i rezhimu orosheniya sel'skokhozyaystvennykh kul'tur [Recommendations on hydro modular zoning and irrigation regime of crops]. Tashkent pp. 48.

SuRENDRAn U., Sushanth C.M., Mammen G., JosePh E.J. 2015. Modelling the crop water requirement using FAOCROPWAT and assessment of water resources for sustainable water resource management: A case study in Palakkad district of humid tropical Kerala, India. Aquatic Procedia. No. 4 p. 1211-1219. DOI 10.1016/j.aqpro.2015.02.154.

Tarjuelo J.M., De-Juan J.A., Moreno M.A., Ortega J.F. 2010. Review. Water resources deficit and water engineering. Spanish Journal of Agricultural Research. No. 8(2) p. 102-121.

USHKARENKO V.O. 1994. Zroshuvane zemlerobstvo: Pidruchnyk [Irrigated agriculture: Textbook]. Kyiv. Urozhaj pp. 326.

USHKARENKO V.O., KOKOVIKHIN S.V., HOLOBORODKO S.P., VozheHOVA R.A. 2014. Metodyka poliovoho doslidu (Zroshuvane zemlerobstvo): Navchalnyi posibnyk [Methodology of the field experiment (Irrigated agriculture): Textbook]. Kherson. Hrin DS. ISBN 978-617-7243-02-0 pp. 443.

VALIPOUR M., SEFidKouhi M.A.G., RAeINI M. 2017. Selecting the best model to estimate potential evapotranspiration with respect to climate change and magnitudes of extreme events. Agricultural Water Management. No. 180 p. 50-60. DOI 10.1016/j.agwat.2016.08.025.

VozHEHOv S.H., KoKOvoKHIN S.V., ZoRINA H.H. 2016. Naukovo-praktychni aspekty modelyuvanniia rezhymiv zroshenniya kul'tur rysovoy sivizminy za dopomohoyu prohramnoho kompleksu CROPWAT [Scientific and practical aspects of modeling the irigation regimes of crops in rice crop rotation 
by using software complex CROPWAT]. Irrigated Agriculture. No 65 p. 54-58.

XU C.Y., SINGH V.P. 2002. Cross comparison of empirical equations for calculating potential evapotranspiration with data from Switzerland. Water Resources Management. No. 16(3) p. 197-219.
ZHURAVLEV O.V. 2016. Osoblyvosti zastosuvannya metodu Penman-Monteith v umovakh kraplynnoho zroshennia Stepu Ukrainy. V: Kraplynne zroshennia iak osnovna skladova intensyvnykh agrotekhnologii XXI stolittia [Peculiarities of Penman-Monteith method use in conditions of drip irrigation of the Steppe zone of Ukraine. In: Drip irrigation as a main part of intensive agrotechnologies of the XXI century] p. 39-43.

\section{Raisa A. VOZHEHOVA, Yurii O. LAVRYNENKO, Serhii V. KOKOVIKHIN, Pavlo V. LYKHOVYD, Iryna M. BILIAIEVA, Antonina V. DROBITKO, Vasyl V. NESTERCHUK}

\section{Ocena wiarygodności programu CROPWAT 8.0 do obliczania ewapotranspiracji i zapotrzebowania roślin na wodę}

\section{STRESZCZENIE}

W artykule przedstawiono wyniki badań poświęconych ocenie dokładności i wiarygodności obliczeń ewapotranspiracji i zapotrzebowania roślin na wodę z zastosowaniem programu CROPWAT 8.0.

Podstawą badań były wyniki wieloletniego eksperymentu polowego prowadzonego od 2012 do 2017 r. na nawadnianych polach południowej Ukrainy z różnymi uprawami: kukurydzy cukrowej, kukurydzy zwykłej, soi i sorgo. Oceniono dokładność wyników uzyskanych za pomocą CROPWAT 8.0 przez porównanie wartości obliczonych z wartościami rzeczywistymi. Stwierdzono znaczne różnice między obliczonymi wartościami ewapotranspiracji upraw i ich zapotrzebowaniem na wodę a wartościami rzeczywistymi z eksperymentów polowych. Największe różnice stwierdzono w przypadku kroplowo nawadnianych upraw kukurydzy cukrowej i wynosiły one 46,05\% w odniesieniu do ewapotranspiracji i $89,20 \%$ do zapotrzebowania na wodę do nawodnień. Obliczenia ewapotranspiracji za pomocą CROPWAT 8.0 były bardziej dokładne w odniesieniu do upraw nawadnianych deszczowniami. Najmniejszą rozbieżność między obliczonymi a rzeczywistymi wartościami badanych parametrów stwierdzono w przypadku deszczowanych upraw kukurydzy zwykłej, gdzie różnice wynosiły $15,86 \%$ w odniesieniu do ewapotranspiracji i $41,63 \%$ do norm nawadniania. Wyniki badań dają podstawy do wnioskowania, że CROPWAT 8.0 nie powinien być stosowany bez wstępnej kalibracji i dostosowania współczynników upraw do konkretnych warunków produkcji rolniczej.

Słowa kluczowe: ewapotranspiracja, kukurydza cukrowa, kukurydza zwykta, nawadnianie, program CROPWAT, soja, sorgo 